\title{
In vitro plant regeneration in rough lemon (Citrus jambhiri Lush.) through epicotyl segments by direct shoot organogenesis
}

\author{
Sukhjit Kaur \\ Punjab Agricultural University, Regional Research Station, Gurdaspur-143521, (Punjab), INDIA \\ E-mail: sukhi.rose@gmail.com \\ Received: September 19, 2015; Revised received: February 9, 2016; Accepted: May 7, 2016
}

\begin{abstract}
The effect of Murashige and Skoog (MS) medium supplemented with various concentrations and combinations of growth hormones on direct regeneration from one month old epicotyl segments of in vitro grown rough lemon (Citrus jambhiri Lush.) seedlings was studied. The earliest bud induction in 7.5 days, highest bud induction frequency (98.50\%), percent regeneration(90.53) were obtained on MS medium supplemented with 6-Benzylaminopurine (BAP) (1 $\left.\mathrm{mglit}^{-1}\right)$ with an average number of 12.50 buds per explants. The epicotyls segments with proliferated buds were transferred to elongation media in order to improve the recovery of normal shoots. Maximum number of elongated shoots (8.50) was obtained on MS medium having BAP $\left(0.5 \mathrm{mglit}^{-1}\right)+$ Gibberellic Acid $\left(\mathrm{GA}_{3}\right)\left(1.0 \mathrm{mglit}^{-1}\right)$. These elongated shoots were then rooted on MS medium containing Indole-3-butyric acid (IBA) $\left(0.1 \mathrm{mglit}^{-1}\right)+$ Indole-3-aceticacid(IAA) $\left(0.5 \mathrm{mglit}^{-1}\right)$ with highest rooting percentage $(96 \%)$ and root number(5.0). Early (10.10 days)

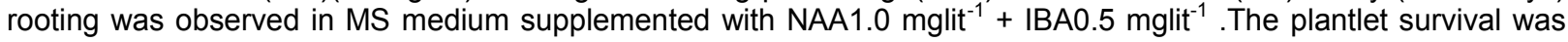
$98.52 \%$, when plantlets were transferred to plastic pots containing a mixture of garden soil and vermiculite (1:1). The hardened plants were successfully established in the soil. The present study developed protocol which can be reliably used for in vitro regeneration of rough lemon and for gene transfer studies in rough lemon, especially to induce salinity and Phytophthora tolerance.
\end{abstract}

Keywords: Citrus jambhiri Lush., Direct regeneration, Epicotyl segments, In vitro, Rooting, Rough lemon

\section{INTRODUCTION}

Citrus fruits are one of the most important fruit crop of the world planted in tropical and subtropical regions. Citrus varieties are propagated by both sexual and asexual methods. Generally, rootstocks are propagated sexually through seeds, while most of the commercial varieties are propagated by various asexual methods (Chaturvedi et al., 2001) that can be used for the production of virus free rootstock plants through micropropagation (Roistacher et al., 1976). Advances in biotechnology have generated new opportunities for citrus genetic improvement. Improvement of citrus by conventional method is hampered by polyembrony, sexual incompatibility and male or female sterility (Guo and Deng, 2001; Grosser and Gmitter, 2005). However, the occurrence of polyembrony in citrus species hinders the production of uniform rootstock population. There is also an urgent need to propagate disease-free planting material for the sustenance of citrus industry, particularly in the northern regions of the country. In vitro multiplication is a technoeconomically viable and eco-friendly approach to produce disease free planting material on a large scale, utilizing relatively small space and time (Thorpe and Harry, 1997). Although several citrus rootstocks have been propagated through tissue culture (Hiregoudar et al., 2005), very few reports are available on in vitro multiplication of Citrus jambhiri (Chaturvedi et al., 2001).The success rate of callus regeneration in Citrus jambhiri is very low (Raman et al., 1992). Moreover, regeneration through callus is not a reliable approach to produce planting material. On the other hand, higher success rate with more number of shoots/explants can be achieved via direct shoot regeneration and this process possesses less probability of somaclonal variation among regenerants in comparison to callus mediated regeneration system is also a necessary pre-requisite for genetic improvement and genetic resource conservation. Genetic transformation is an alternative to overcome these difficulties. For successful transformation, regeneration of whole plants from the transformed cells is a prerequisite. For hormone, the effect of auxin on shoot regeneration was rarely concerned, though the main hormone effect on bud formation was due to the addition of Benzyl adenine (Garcia-Luis et al., 1999). In vitro propagation has therefore been a great potential tool to overcome problems related with the field culture for such species (Hidaka and Omara, 1989). Genotype affects the morphogenic response of in vitro grown epicotyl segments of citrus rootstocks. The qualitative and quantitative differences in the organogenic response indicated that the conditions for regeneration must be optimized for each genotype 
(Bordon et al., 2000). Tissue culture of rough lemon has also been studied by Raman et al.(1992); Altaf and Ahmad(1997); Ali and Mirza (2006); Saini et al. (2010); Rattanpal et al.(2011). Furthermore, an efficient system of regeneration through organogenesis is the step for genetic transformation of these species (Gmitter et al.,1992).This study was conducted with aim to explore regenerative ability via direct regeneration, appropriate media and epicotyl segments as explants of rough lemon (Citrus jambhiri Lush). The significance of the present study to develop the protocol which can be used successfully for the plant micropropagation and genetic transformation of rough lemon (Citrus jambhiri Lush) .

\section{MATERIALS AND METHODS}

Plant material and explant preparation: The experimental material consisted of seeds extracted from ripened fruits of citrus rootstock rough lemon (Citrus jambhiri Lush.) collected from the Citrus germplasm collection block of New Orchard of Department of Fruit Science, Punjab Agricultural University, Ludhiana during 2009-10 and 2010-11. Fresh fruit taken from field grown trees were washed with water containing 1-2 drops of teepol and then washed thoroughly with running tap water. The seeds extracted from fruits were removed of testa (outer covering) and then surface sterilized under aseptic conditions with mercuric chloride $0.1 \%(\mathrm{w} / \mathrm{v})$ for $4-5$ minutes. The seeds were thoroughly washed with sterilized distilled water thrice before inoculation to remove the toxic effects of mercuric chloride. After sterilization, seeds were sown in Murashige and Skoog (1962) basal medium in culture jars. The cultured seeds were incubated at $25 \pm 2^{\circ} \mathrm{C}$ temperature in dark for two weeks for etiolation. After one week of sowing, seed germination started. After 4-5 weeks, these culture were shifted to light for 16 hours continuous fluorescent white light (2000lux) followed by a dark period of 8 hours.

In vitro direct shoot regeneration/proliferation: Epicotyl segments $(1-2 \mathrm{~cm})$ from one month old seedlings were cultured on different direct shoot regeneration medias were incubated at $25 \pm 2^{\circ} \mathrm{C}$ temperature for 16 hours continuous florescent white light (2000 lux) followed by a dark period of 8 hours to produce maximum number of adventitious shoot buds and to know the efficiency of regeneration with different media in petri dishes. Explants with proliferated shoot buds, formed under optimal condition, were transferred to elongation medium. The number of elongated shoots $(>1 \mathrm{~cm}$ and $>2 \mathrm{~cm})$ was counted after four weeks of culture.

In vitro root induction and acclimatization: Elongated shoots were placed vertically in $25 \times 150 \mathrm{~mm}$ culture tubes containing $25 \mathrm{ml}$ of different root induction medium. The percentage of shoots rooted, days to root, an average number of roots/shoot and root length were recorded after four weeks of culture. The in vitro rooted plantlets were removed from the culture tubes, thoroughly washed under running tap water and placed into plastic pots containing different potting mixture of garden soil, sand and vermiculite (1:1). Initial watering was done using $0.1 \%$ Bavistin solution to reduce the mortality of plants due to fungal pathogens. The percent survival of plantlets in different potting mixtures was recorded.

Statistical analysis: The experimental data was analysed with Completely Randomized Block Design as described by Singh et al. (1998).

\section{RESULTS AND DISCUSSION}

Direct shoot regeneration from epicotyl segments: The response of epicotyl segments for direct regeneration was assessed on different media containing MS fortified with variable concentrations of BAP and 1Nephthalene acetic acid (NAA)(Table 1). The significant differences among the culture media were recorded. The number of days taken to regeneration (7.50), percent regeneration (90.53), bud induction frequency (98.50\%) and average number of buds (12.50) were significantly higher on MS medium supplemented with BAP1mglit ${ }^{-1}$ followed by MS medium fortified with BAP $0.5 \mathrm{mglit}^{-1}$. The lowest bud induction frequency $(50.00 \%)$, average number of buds(2.15), shoot regeneration response $(25.50 \%)$ was observed on MS medium supplemented with BAP1mglit ${ }^{-1}+\mathrm{NAA}$ $0.1 \mathrm{mglit}^{-1}$ with more (14.82) number of days taken for regeneration(Table1). These results find support from the previous workers like Costa et al. (2002) reported shoot regeneration at Benzyl adenine (BA) from 0.5$4.0 \mathrm{mglit}^{-1}$ with the best at $2 \mathrm{mglit}^{-1}$ for Citrus paradisi Macf. epicotyl explants. Te-Chato and Nudong (1998) reported that BA $0.5 \mathrm{mglit}^{-1}$ gave the best results(75\%) of shooting response in Citrus reticulate Blanco cultivar Shogun from different explants of invitro raised seedlings. The results of the present study are in agreement with the previous reports as in most citrus species epicotyls and stem segments have been used as explants for direct regeneration with MS medium supplemented with BA $3 \mathrm{mglit}^{-1}$ or BA $1 \mathrm{mglit}^{-1}$ (Ghorbel et al., 1999; Pena and Navarro, 1999; Dominguez et al., 2000; Cervera et al., 2000). However, Kaneyoshi et al.(1994) reported adventitious bud formation using MS medium supplemented with BA 5 mglit $^{-1}$ and NAA0.1 mglit ${ }^{-1}$ in Poncirus trifoliata Rad. But, Ali and Mirza (2006) reported the maximum shoot regeneration with MS medium supplemented with BA $3 \mathrm{mglit}^{-1}$ from stem and epicotyl segments of rough lemon. Dejam et al.(2006) also reported that the highest percentage of explants with the adventitious buds was obtained in concentration of MS+2mg lit ${ }^{-1}$ of BA. Nwe et al.(2014) reported that cotyledonary node explants cultured on Murashige and Skoog (MS) medium supplemented with $8.88 \mu \mathrm{M}$ N6benzyladenine (BA) and $0.54 \mu \mathrm{M} \alpha$-naphthaleneacetic 
Table 1. Effect of different media on the bud induction and percent regeneration of epicotyl segments of rough lemon (C. jambhiri Lush.) .

\begin{tabular}{|c|c|c|c|c|}
\hline Media & $\begin{array}{l}\text { Days to bud } \\
\text { induction }\end{array}$ & $\begin{array}{l}\text { Bud induction } \\
\text { frequency }(\%)\end{array}$ & $\begin{array}{l}\text { Percent re- } \\
\text { generation }\end{array}$ & $\begin{array}{l}\text { Average number of } \\
\text { adventitious buds }\end{array}$ \\
\hline MS+BAP (1mglit $\left.{ }^{-1}\right)$ & 7.50 & 98.50 & 90.53 & 12.50 \\
\hline $\mathrm{MS}+\mathrm{BAP}\left(0.5 \mathrm{mglit}^{-1}\right)$ & 9.00 & 88.05 & 80.50 & 9.76 \\
\hline $\mathrm{MS}+\mathrm{BAP}\left(3 \mathrm{mglit}^{-1}\right)+\mathrm{NAA}\left(0.1 \mathrm{mglit}^{-1}\right)$ & 9.50 & 85.12 & 75.23 & 8.00 \\
\hline $\mathrm{MS}+\mathrm{BAP}\left(3 \mathrm{mglit}^{-1}\right)+\mathrm{NAA}\left(0.2 \mathrm{mglit}^{-1}\right)$ & 10.80 & 82.00 & 70.51 & 7.50 \\
\hline $\mathrm{MS}+\mathrm{BAP}\left(2 \mathrm{mglit}^{-1}\right)+\mathrm{NAA}\left(0.1 \mathrm{mglit}^{-1}\right)$ & 11.51 & 80.25 & 65.33 & 5.00 \\
\hline $\mathrm{MS}+\mathrm{BAP}\left(2 \mathrm{mglit}^{-1}\right)+\mathrm{NAA}\left(0.2 \mathrm{mglit}^{-1}\right)$ & 12.03 & 75.00 & 60.25 & 4.00 \\
\hline $\mathrm{MS}+\mathrm{BAP}\left(1 \mathrm{mglit}^{-1}\right)+\mathrm{NAA}\left(0.2 \mathrm{mglit}^{-1}\right)$ & 13.82 & 60.50 & 50.00 & 3.25 \\
\hline $\mathrm{MS}+\mathrm{BAP}\left(1 \mathrm{mglit}^{-1}\right)+\mathrm{NAA}\left(0.1 \mathrm{mglit}^{-1}\right)$ & 14.82 & 50.00 & 25.50 & 2.15 \\
\hline $\mathrm{CD}(5 \%)$ & 1.65 & 2.86 & 2.83 & 1.42 \\
\hline
\end{tabular}

Table 2. Effect of different media on bud elongation in rough lemon (C. jambhiri Lush.) .

\begin{tabular}{|c|c|c|c|}
\hline \multirow[t]{2}{*}{ Media } & \multicolumn{2}{|c|}{ Percent Bud elongation } & \multirow[t]{2}{*}{ Average number of shoots } \\
\hline & $(>1 \mathrm{~cm})$ & $(>2 \mathrm{~cm})$ & \\
\hline $\mathrm{MS}+\mathrm{GA}_{3}\left(1.0 \mathrm{mglit}^{-1}\right)$ & 22.25 & 6.50 & 3.24 \\
\hline $\mathrm{MS}+\mathrm{BAP}\left(0.5 \mathrm{mglit}^{-1}\right)+\mathrm{GA}_{3}\left(1.0 \mathrm{mglit}^{-1}\right)$ & 40.20 & 18.45 & 8.50 \\
\hline $\mathrm{MS}+\mathrm{BAP}\left(2.0 \mathrm{mglit}^{-1}\right)+\mathrm{GA}_{3}\left(1.0 \mathrm{mglit}^{-1}\right)$ & 31.50 & 10.35 & 6.50 \\
\hline $\mathrm{MS}+\mathrm{BAP}\left(1.0 \mathrm{mglit}^{-1}\right)($ Control$)$ & 11.35 & 1.00 & 2.00 \\
\hline $\mathrm{CD}(5 \%)$ & 3.67 & 2.21 & 1.18 \\
\hline
\end{tabular}

acid (NAA) developed more than five shoots per explant.The best results were obtained with $1 \mathrm{mg}$ lit $^{-1}$ BAP for bud induction (Almeida et al.,2002). It has been possible to obtain the adventitious shoot formation (caulogenesis) by the cultivation of epicotyl and internodal segments in culture mediums containing BAP in combination with NAA (Bordon et al., 2000; MoreiraDias et al., 2000, 2001) or BAP alone (Moura et al., 2001; Almeida et al., 2002; Silva et al., 2005). Rezadost et al.(2013) reported that the highest percentage of responsive explants (90\%) obtained by using $2.5 \mathrm{mg}$ $\operatorname{lit}^{-1}$ BAP in combination with the $0.05 \mathrm{mg} \mathrm{lit}^{-1} \mathrm{NAA}$ which had 2 days pre-culture period of epicotyls for allowing to grow in the absolute darkness for 4 weeks, followed by 10 days in 16 hours photoperiod. The highest number of well-developed shoots was 4.2 shoots per explant and obtained with medium containing $0.5 \mathrm{mg} \mathrm{lit}^{-1} \mathrm{GA}_{3}$.Silva et al. (2010) by culturing Citrus aurantium epicotyl segments in MT (Murashige and Tucker, 1969) medium containing $1 \mathrm{mglit}^{-1} \mathrm{BAP}$ and $0.3 \mathrm{mglit}^{-1} \mathrm{NAA}$ were able to achieve $80.9 \%$ regeneration efficiency from which 3.1 buds per explants attained.

The constituents of culture medium play an important role in the process of tissue differentiation. The beneficial effects of cytokinins has been reported in the induction of shoot bud primordial in different crop plants (Lesham,1973), which may be due to more synthesis of nucleic acids and proteins required for organogenesis (Torres, 1988).The cytokinins are generally added to induce shoot formation and to inhibit root formation.

Shoot elongation: The adventitious buds induced on MS medium supplemented with BAP $\left(1 \mathrm{mglit}^{-1}\right)$ were further sub-cultured on different elongation media. Because of the short size of buds induced, an elongation phase was necessary. It was noted that MS+BAP $\left(0.5 \mathrm{mglit}^{-1}\right)+\mathrm{GA}_{3}\left(1.0 \mathrm{mglit}^{-1}\right)$ medium gave maximum (40.20) shoot elongation $(>1 \mathrm{~cm})$ followed by
$\mathrm{MS}+\mathrm{BAP}\left(2.0 \mathrm{mglit}^{-1}\right)+\mathrm{GA}_{3}\left(1.0 \mathrm{mglit}^{-1}\right)(31.50 \%)$ (Table2).Similarly maximum shoot elongation (18.45\%) of $>2 \mathrm{~cm}$ in length was observed in $\mathrm{MS}+$ BAP $\left(0.5 \mathrm{mglit}^{-}\right)+\mathrm{GA} 3\left(1.0 \mathrm{mglit}^{-1}\right)$ medium followed by MS+ BAP $\left(2.0 \mathrm{mg} \mathrm{lit}^{-1}\right)+\mathrm{GA}_{3}\left(1.0 \mathrm{mglit}^{-1}\right)(10.35 \%)$. Minimum shoot elongation was observed in control $\left(\mathrm{MS}+\mathrm{BAP}\left(1.0 \mathrm{mglit}^{-1}\right)(\right.$ Table2). Similar results were noted by Saini et al. (2010) in that the shoot elongation percentage was maximum in MS medium fortified with BAP $0.5 \mathrm{mglit}^{-1}$ and $\mathrm{GA}_{3} 1.0 \mathrm{mglit}^{-1}$. The number of elongated shoots was improved with the addition of BA alone or with $\mathrm{GA}_{3}$ to the elongation medium. In the present study, possibly lower concentration of BA continued to stimulate shoot initiation, while reducing the dominance of newly formed buds, whereas $\mathrm{GA}_{3}$ promoted the elongation of shoot buds initiated on the induction medium. Omura and Hidaka (1992) also observed that the addition of cytokinin and $\mathrm{GA}_{3}$ was found necessary for successful shoot tip culture of citrus .

Rooting of regenerated shoots: The root induction from in vitro produced shoots of rough lemon started with in 10-20 days on various modification of MS medium. About 2-3 cm lengthy in vitro regenerated shoots were separated out from epicotyls segments and transferred to the different rooting media. Among the seven media evaluated for rooting response, the percent rooting was maximum (96.00) on MS fortified with IBA $0.1 \mathrm{mglit}^{-1}$ and IAA $0.5 \mathrm{mglit}^{-1}$, where as it was minimum (65.50) on MS fortified with NAA 1.0 mglit $^{-1}$ and IBA 0.5 mglit $^{-1}$ (Table3). Rooting was significantly earlier (10 days) on MS fortified with NAA 1.0 mglit $^{-1}$ and IBA $0.5 \mathrm{mglit}^{-1}$, where as it was delayed on rest of media with maximum duration (20.52 days) on MS supplemented with IBA 1.0 mglit $^{-1}$. Number of roots were significantly higher in MS medium fortified with IBA0.1 $\mathrm{mglit}^{-1}$ and IAA 0.5 
Table 3. Effect of different media on rooting response of direct regenerated shoots from epicotyl segments of rough lemon ( $C$. jambhiri Lush.).

\begin{tabular}{|c|c|c|c|c|}
\hline Media & Rooting percentage & Days to rooting & Number of roots & Root length(cm) \\
\hline $\mathrm{MS}+\mathrm{IBA}\left(0.1 \mathrm{mglit}^{-1}\right)+\mathrm{IAA}\left(0.5 \mathrm{mglit}^{-1}\right)$ & 96.00 & 14.11 & 5.00 & 9.96 \\
\hline $\mathrm{MS}+\mathrm{IBA}\left(0.5 \mathrm{mglit}^{-1}\right)+\mathrm{IAA}\left(0.5 \mathrm{mglit}^{-1}\right)$ & 90.00 & 17.00 & 4.50 & 10.00 \\
\hline $\mathrm{MS}+\mathrm{IBA}\left(1.0 \mathrm{mglit}^{-1}\right)$ & 84.50 & 20.52 & 2.31 & 9.91 \\
\hline $\mathrm{MS}+\mathrm{NAA}\left(0.5 \mathrm{mglit}^{-1}\right)$ & 80.52 & 15.50 & 3.28 & 10.00 \\
\hline $\mathrm{MS}+\mathrm{IBA}\left(0.5 \mathrm{mglit}^{-1}\right)+\mathrm{IAA}\left(0.1 \mathrm{mglit}^{-1}\right)$ & 78.21 & 13.00 & 2.00 & 9.92 \\
\hline $\mathrm{MS}+\mathrm{NAA}\left(1.0 \mathrm{mglit}^{-1}\right)+\mathrm{IBA}\left(1.0 \mathrm{mglit}^{-1}\right)$ & 70.58 & 12.51 & 1.82 & 9.90 \\
\hline $\mathrm{MS}+\mathrm{NAA}\left(1.0 \mathrm{mglit}^{-1}\right)+\mathrm{IBA}\left(0.5 \mathrm{mglit}^{-1}\right)$ & 65.50 & 10.10 & 1.52 & 10.00 \\
\hline $\mathrm{CD}(5 \%)$ & 3.03 & 2.03 & 1.19 & NS \\
\hline
\end{tabular}

Table 4. Effect of different potting mixtures on the percent survival of the plantlets of rough lemon (C. jambhiri Lush.)

\begin{tabular}{ll}
\hline Potting Mixtures & Percent survival \\
\hline Garden soil & \\
Garden soil + sand(1:1) & 60.36 \\
Garden soil + sand(1:2) & 75.5 \\
Garden soil + sand(2:1) & 70.20 \\
Garden soil + vermiculite $(1: 1)$ & 65.75 \\
Garden soil + vermiculite $(1: 2)$ & 98.52 \\
Garden soil + vermiculite $(2: 1)$ & 88.25 \\
CD $(5 \%)$ & 92.45 \\
\hline
\end{tabular}

mglit $^{-1}$, where as root length was found to be non-significant irrespective of media (Table3)

Similarly, Raman et al.(1992) also reported the rooting of the excised shoots derived from stem derived callus of rough lemon with the addition of NAA $1 \mathrm{mglit}^{-1}$ and sucrose $(2 \%)$ to the $1 / 2$ MS medium. In this study, rooting of high frequency was achieved even in $1 / 2$ MS medium devoid of growth regulators. This can be explained on the basis of growth regulators composition of shoot regeneration medium. In this study, the shoot differentiation was achieved in medium containing NAA 0.5 mglit $^{-1}$, BA 3.0 mglit $^{-1}$ and kinetin 0.5 mglit $^{-1}$. Thus, the shoots were rich in endogenous auxin content and when transferred to the $1 / 2 \mathrm{MS}$ medium, rooting was induced.

Previous workers also reported the supplementation of MS media with IBA alone (Oh et al.,1991) or in combination (Chakravarty and Gosami,1999) and NAA alone (Das et al.,2000) has induced roots in the shoots of different citrus species. Similarly, Parkash (2003) observed the earliest and maximum rooting in Citrus jambhiri Lush. on MS supplemented with NAA $1.0 \mathrm{mg} \mathrm{lit}^{-1}$ and IBA $1.0 \mathrm{mg}$ lit $^{-1}$. Auxins play an important role in rhizogenesis, which include division of meristematic cells, their elongation and differentiation into root primordial (Omura and Hidaka, 1992). The number of roots produced per shoot, root length and thickness of roots varied with the concentration and combination of auxins used in the medium. Many workers also reported the maximum rooting response on MS+NAA(1.5-2 $\left.\mathrm{mglit}^{-1}\right)$ in Pectinifera rootstock (Gill and Gosal,2002) and Citrus sinensis cv. Mosambi (Rashad et al.,2005).

Acclimatization: The rooted plantlets were first hardened in vitro for 5-6 days in the incubation room and kept over moist cotton soaked in half MS salts. The plantlets in MS solution exhibited fresh root growth. This process of hardening acclimatized the plantlets for their subsequent transfer to soil. After hardening, the plantlets were transferred to different potting mixtures in plastic pots, in which they exhibited varied survival rates (Table 4).The maximum plantlet survival $(98.52 \%)$ was observed in garden soil + vermiculite $(1: 1)$ potting mixture. Similar results were noted by Saini et al. (2010) that the maximum plantlet survival was noted in garden soil + vermiculite (1:1) potting mixture. In this experiment, the rooted plantlets grown in all the potting mixtures exhibited low mortality of the plantlets because vermiculite had high water holding capacity.

\section{Conclusion}

The present study concluded that the maximum $(90.53 \%)$ and earliest (7.5 days) shoot regeneration response was in epicotyls segments cultured on MS medium supplemented with BAP 1 mglit $^{-1}$. Early (10.10 days) rooting was observed in MS medium supplemented with NAA1.0 glit $^{-1}+$ IBA $^{0.5}$ mglit $^{-1}$ and the highest $(96 \%)$ rooting percentage was noted in MS medium supplemented with IBA0.1 mg lit ${ }^{-1}+$ IAA $0.5 \mathrm{mglit}^{-1}$. The present work defined organogenesis and plant regeneration protocols for rough lemon (Citrus jambhiri Lush) which can be used in plant transformation experiments.

\section{REFERENCES}

Ali, S. and Mirza, B. (2006). Micropropagation of rough lemon(Citrus jambhiri Lush.):Effect of explant type and hormone concentration. Acta Botanica Croatica.65 (2):137-146.

Almeida, W.A.B., Filho, F.A.A.M., Mendes, B.M.J. and Rodriguez, A.P.M. (2002). In vitro organogenesis optimization and plantlet regeneration in Citrus sinensis and Citrus limonia. Scientia Agricola. 59(1): 35-40.

Altaf, N. and Ahmad, M.S. (1997). Effect of culture medium 
composition on nucellar embryogenesis in three citrus cultivars: Kinnow, Jatti Khatti (Rough lemon) and Gada Dehi. In Endeavors in Biotechnology. Pp. 25-30.Edited by Ihsan Iiahi, Department of Botany, University of Peshawar.

Bordon, Y., Guardiola, J.I. and Garcia-Luis, A. (2000). Genotype affects the morphogenic response invitro epicotyl segments of citrus rootstocks. Annals of Botany. 86:156-166.

Cervera, M., Ortega, C., Navarro, A., Navarro, L. and Pena, L. (2000). Generation of Transgenic citrus plants with tolerance to salinity gene HAL2 from yeast. The Journal of Horticultural Science and Biotechnology. 75 (1):26-30.

Chakravarty, B. and Goswami, B.C. (1999). Plantlet regeneration from term callus cultures of Citrus acida Roxb. and the uniformity of regenerated plants. Scientia Horticultura. 82(1-2):159-69.

Chaturvedi, H.C., Singh, S.K., Sharma, A.K. and Agnihotri, S. (2001). Citrus tissue culture employing vegetative explants. Indian Journal of Experimental Biology. 39 (11): 1080-1095.

Costa, M.G.C., Otoni, W.C. and Moor, G.A. (2002). A elevation of factors affecting the efficiency of Agrobacterium mediated transformation of Citrus paradise Macf. and production of transgenic plants containing carotenoid biosynthetic genes. Plant Cell Reports. 21 (4): 365-373.

Das, A., Paul, A.K. and Chaudhuri, S. (2000). Micropropagation of sweet orange (Citrus sinensis Osb.) for the development of nucellar seedlings. Indian Journal of Experimental Biology. 38: 269-272.

Dejam, M., Khosh-Khui, M. and Shekafandeh, A. (2006). Adventitious bud induction and plant regeneration in epicotyl segments of Bakrai (Citrus reticulata Blanco. $\mathrm{x}$ Citrus limetta Swing.). International Journal of Agricultural Research.1(1):14-19.

Dominguez, A., Guerri, J., Cambra, M., Navarro, L., Moreno, P., and Pena, L.S. (2000). Efficient production of transgenic citrus plants expressing the coat protein gene of citrus tristeza virus. Plant Cell Reports .19(4): 427-433.

Garcia-Luis, A., Bordon, Y., Moreira-Dias, J.M., Molina, R. and Guardiola, J.L. (1999). Explant orientation and polarity determine the morphogenic response of epicotyl segments of Troyer citrange. Annals of Botany (London) .84: 715-723.

Ghorbel, R., Juarez, J., Navarro, L., Pena, L. (1999). Green fluorescent protein as a screenable marker to increase the efficiency of generating transgenic woody fruit plants. Theoretical and Applied Genetics. 99(1-2): 350358.

Gill, M.I.S. and Gosal S.S. (2002). Micropropagation of pectinifera (Citrus depressa Hayata) a potential citrus rootstock for sweet orange. Indian Journal of Citriculture. 1(1):32-37.

Gmitter, F.G., Grosser, J.W. and Moore, G.A. (1992). Citrus. In. F.A. Hamerschlag and R.E. Litz (Editors), Biotechnology of Perennial Fruit Crops. CAB International, Wallingford, pp:335-369.

Grosser, J.W. and JR. Gmitter, F.G. (2005). Applications of somatic hybridization and cybridization in crop improvement, with citrus as a model. In vitro Cellular and Developmental Biology.41:220-225.

Guo, W.W. and Deng, X.X .(2001). Wide somatic hybrids of citrus with its related genera and their potential in genetic improvement. Euphytica .118:175-183.

Hidaka, T. and Omura, M. (1989). Control of embryogenesis in citrus cell culture regeneration protoplasts and attempts to callus culture bank. Bulletin of the fruit tree research station, series okitsu. 16:1-17.

Hiregoudar, L., Ashok Kumar, H.G. and Murthy, M.N. (2005). In vitro culture of Feronia lemonia (L.) Swingle from hypocotyl and internodal explants. Biologia Plantarum. 49(1):41-45.

Kaneyoshi, J., Kobayashi, S., Nakamura, Y., Shigemoto, N., and Doi, Y. (1994). A simple and efficient gene transfer system to trifoliate orange (Poincirus trifoliate Raf). Plant Cell Reports. 13(10): 541- 545.

Lesham, Y. (1973). Molecular and hormonal basis of plant growth regulation( Pergamon Press,New York), 35-86.

Moreira-Dias, J.M., Molina, R.V., Bordon, Y., Guardiola, J.L. and Garcia-Luis, A .(2000). Direct and indirect shoot organogenic pathways in epicotyl cuttings of Troyer citrange differ in hormone requirements and in their response to light. Annals of Botany(London). 85 (1):103-110.

Moreira-Dias, J,M, Molina, R,V., Guardiola, J.L. and Garcia-Luis, A. (2001). Day-length and photon flux density influence the growth regulator effects on morphogenesis in epicotyl segments of Troyer citrange. Scientia Horticulturae.87(4): 275-290.

Moura, T.L.M., Almeida, W.A.B., Mendes, B.M.J. and Mourao Filho, F.A.A . (2001). Organogênese in vitro de Citrus em função de concentrações de BAP e seccionamento do explante. Revista Brasileira de Fruticultura. 23(2): $240-245$

Murashige, T. and Skoog, F. (1962). A revised medium for rapid growth and bioassay with tobacco tissue culture. Physiologia Plantarum. 15:473-479.

Murashige, T. And Tucker, D.P.H. (1969). Growth factor requirement of citrus tissue culture. In: International Citrus Symposium,1, Riverside. Proceedings. Riverside: University of California. 3:1155-1169.

Nwe, Y.Y., Myint, K.T., Mochizuki, Y., Vazirzanjani, M., Okayasu, K., Suzuki, S. and Ogiwara, I. (2014). In vitro regeneration through direct shoot organogenesis in Honey Orange (Citrus tangerina). Plant Biotechnology. 31(4): 341-344.

Oh, S.D., Song, W.S., Cho, H.M. and Baek, S.H. (1991). Plant regeneration in dangyooza (Citrus grandis Osb.) through somatic embryogenesis. 3. Effect of different combinations or alone of complex addenda, sucrose and 2,4-D on somatic embryogenesis. Research Reports of the Rural Development Administration Biotechnology. 33: 33-37.

Omura, M and Hidaka, T. (1992). Shoot tip culture of citrus. Bulletin of the Fruit Tree Research Station. 22 : 23-35.

Parkash, O. (2003). Studies on invitro plantlet production and acclimatization of rough lemon (Citrus jambhiri Lush.). M.Sc. Thesis, Punjab Agricultural University, Ludhiana.

Pena, L. and Navarro, L. (1999). Transgenic citrus. In: Y.P.S.(ed.), Biotechnology in Agriculture and Forestry, Vol.44,Transgenic Tress, pp.39-54. Springer-Verlag, Berlin, Germany.

Raman, H., Gosal, S.S. and Brar, D.S. (1992). Plant regeneration from callus culture of Citrus limon and $C$ jambhiri. Crop Improvement. 19 (2):100-103.

Rashad, M., Khan, M.M., Ramzan, R., Adnan, S. and Khan, 
F.A. (2005). In vitro regeneration and somatic embryogenesis in Citrus autantifolia and Citrus sinensis. International Journal of Agriculture and Biology. 7(2): 518-520.

Rattanpal, H.S., Kaur, G. and Gupta, M. (2011). In vitro plant regeneration in rough lemon (Citrus jambhiri Lush) by direct organogenesis. African Journal of Biotechnology, 10(63):13724-13728.

Rezadost, M.H., Sohani, M.M., Hatamzadeh, A. and Reza, M. (2013). In vitro regeneration of sour orange (Citrus aurantium L.) via direct organogenesis. Plant Knowledge Journal. 2(4):150-156 .

Roistacher, C.N., Navarro, L. and Murashige, T. (1976). Recovery of citrus selections free of several viruses, exocortis viroid and spiroplasma citri by shoot-tip grafting in vitro. Proceedings $7^{\text {th }}$ Conference International Organization Citrus Virologists, IOCV, Riverside, 186193.

Saini, H.K., Gill, M.S. and Gill, M.I.S. (2010). Direct shoot organogenesis and plant regeneration in rough lemon (Citrus jambhiri Lush.). Indian Journal of Biotechnology. 9(4): 419-423.
Silva, R.P., Costa, M.A.P.C., Souza, A.S. and Almeida, W.A.B. (2005). Regeneracao de plantas de laranja-Pera via organogênese invitro. Pesquisa Agropecuaria Brasileira. 40(12):1153-1159.

Silva, R.P., Souza, A.J., Mendes, B.M.J. and Mourao Filho, F.A.A. (2010). Sour orange bud regeneration and in vitro plant development related to culture medium composition and explant type. Revista Brasileira de Fruticultura .32(1):1-8.

Singh, S., Bansal, M.L., Singh, T.P. and Kumar, P. (1998). Statistical Methods for Research Workers. Kalyani Publishers, New Delhi.

Te-Chato, S. and Nudoung, S. (1998). Tissue culture of Citrus reticultata Blanco cv. Shogum and gene transformation by Agrobacteria. Proc. Abstracts IMT-GT UNITE Conf. Songkxhla.

Thorpe, T.D. and Harry, I.S. (1997). Application of tissue culture to horticulture (In: Horticultural biotechnology, edited by A Altaian \& M Ziv. Acta Horticulturae. 447:39-49.

Torres, K.C. (1988). Tissue culture technique for horticultural crops (Vam Mostrand Reinhold, New York), 295-298. 